Academic Voices

A Multidisciplinary Journal

Volume 3, No. 1, 2013

ISSN 2091-1106

\title{
Editorial
}

\section{ADMIRE AHEAD}

"Don't walk behind me; I may not lead. Don't walk in front of me; I may not follow. Just walk beside me and be my friend."

- Albert Camus

The third volume of "Academic Voices" is in your hand. This volume is just a continuation of a "Little Effort" initiated in 2011, "Maintaining the Legacy" and now I feel it is "Admire Ahead". I would like to encourage our authors in this editorial by a quotation of a famous writer.

"And by the way, everything in life is writable about if you have the outgoing guts to do it, and the imagination to improvise. The worst enemy to creativity is self-doubt."

-Sylvia Plath

I have the privilege to write this editorial on behalf of editorial team of "Academic Voices" and it is a great pleasure as well as pride for me. In my feelings, Academic Voices Journal has proven a catalyst to enhance the creative skills among the teaching faculties of Thakur Ram Multiple Campus. The present volume of the journal comprises three valuable articles in Science, eight in Education, three in Management and five articles in Humanities and Social Sciences.

Among the articles from Science, Triaryl Antimony (V) derivatives show efficient insecticidal and bactericidal properties is the theme report of Ram Nath Prasad Yadav. The research findings reported here by Umesh Prasad Shrivastava focus on the plant growth promoting rhizobacteria present in the rice rhizosphere of Varanasi and East Champaran districts of India. Shambhu Prasad Patel has reported the actual scenario of HIV/AIDS among drivers in Birganj Bus Park.

Likewise the articles from Education, Bhawani Prasad Mainali has given emphasis on decentralization of education planning and its impact in quality; Rajkumar Yadav has reviewed the age of female at the time of marriage and their fertility among Tharu community in certain regions of Nepal and Rajendra Thakur has reported the demographic changes of Hajam (Thakur) community. Similarly, Subhash Prasad has explained the knowledge and practices being used among HIV/AIDS injecting drug users. Tara Bahadur Thapa has made an attempt to analyse students' conflict in schools. Goal strategies and programme of safe motherhood in Nepal has been described jointly by KamlaVashisth, and Om Prasad Baral. 
Moreover in the articles from Humanities and Social Sciences, Basudevlal Das has described the situation of Maithili language in medieval Nepal; Yadab Raj Sharma has critically reviewed the trends of taxation in Nepal; Sushma Tiwari has documented a case study on political awareness among the Madheshi women of Parsa district; and Shiva Kant Dube has reviewed the opportunities and threats of green revolution in the context of Parsa district of Nepal.

Furthermore, the articles in Management, Sanjay Shrestha has explored the concept of dividend irrelevance theory; Ganesh Prasad Niraula has explained about the benefit of motivation as the most important tool for modern organizations and human resource planning in Nepalese business enterprises is the main theme of the article of Manoj Kumar Chaurasiya.

Some articles are with a different flavour as they are in our national language having Devanagari script. Balaram Dahal has given emphasis on "Makawani Bala Mahakabya" of Umanath Shastri Sindhuliye. Manju Shrestha has reported the miseries of the women caused by Armed Revolution of the Maoists in Nepal and Indra Prasad Bhattarai has discussed the theoretical aspects of "Katha".

At last, I would like to express my sincere gratitude to Mr. Lalan Dwibedi, the Campus Chief of Thakur Ram Multiple Campus for financial support and persuasion for enhancing research activities. The contributing authors are duly acknowledged. The editorial team is very sorry for not incorporating a couple of articles as they did not meet the academic rigor required by the journal.

Finally, with all modesty and sincerity I acknowledge each and everyone for their contribution for giving this journal a real shape.

\section{Umesh Prasad Shrivastava}

Editor, Academic Voices 